\title{
Does the geometric and linear morphometry of the brain reflect the divergence in the "guentheri" group (Arvicolinae, Sumeriomys)?
}

\author{
Tanya Zorenko*, Ugis Kagainis \& Lyubova Barashkova
}

\begin{abstract}
The purpose of this work is to investigate the divergence of the brain' size and shape of three vole's taxa of "guentheri" group using geometric and linear morphometric analysis. The obtained data show that the sex factor does not affect the brain's linear parameters and shape of the studied taxa that indicates a weak effect of the sexual selection on morphological adaptation and variability of the brain structure. The linear measurements of the investigated taxa differ significantly by all signs ( 24 parameters). The obtained data indicate that the divergence of Microtus guentheri and M. hartingi is the most significant (92\%) that obviously is associated with ancient isolation of this species by Anatolian Diagonal. The differences between the two subspecies (M. hartingi hartingi and M. h. lydius) are much smaller $-63 \%$. It should be noted that the vole of the Strandzha Mountain - M. h. strandzensis differs from the $M$. h. hartingi and M. h. lydius significantly more -82 and $75 \%$, respectively. These differences may reflect the history of the investigation of voles from Anatolia to Europe. Geometric deformities of the brain of all taxa are found. Analysis of canonical variations showed that all three taxa differ significantly, both laterally and dorsally. Comparison of taxa lateral views showed that $M . h$. lydius brain is more flatten than $M$. h. hartingi, but M. guentheri has a broader brain and a smoother outer olfactory tract as well as smaller olfactory bulbs. By dorsal view, deformation of M. guentheri brain at the attachment sites of the cerebellum hemisphere to the cerebral hemisphere is observed, while the cerebellum worm of $M$. $h$. lydius is more flattened. The factors affecting the diversity of brain complexity could include allometry, phylogeny and natural selection. The accelerated morphological evolution of the "guentheri" group can be explained by the fragmentation of the range and habitats.
\end{abstract}

How to cite this article: Zorenko T., Kagainis U., Barashkova L. 2020. Does the geometric and linear morphometry of the brain reflect the divergence in the "guentheri" group (Arvicolinae, Sumeriomys)? // Russian J. Theriol. Vol.19. No.1. P.45-57. doi: 10.15298/rusjtheriol.19.1.04.

KEY WORDS: geometric morphometrics, brain structures, size and shape, morphological divergence, geographical isolation, Microtus guentheri, Microtus hartingi.

Tanya Zorenko[tatjana.zorenkot@lu.lv],Lyubova Barashkova [lubova.baraskova@gmail.com],Department of Zoology and Animal Ecology, Faculty of Biology, University of Latvia, 1 Jelgava's Street, LV-1004, Riga, Latvia; Ugis Kagainis [ugis.kagainis@lu.lv], Department of Zoology and Animal Ecology, Faculty of Biology, University of Latvia, 1 Jelgava's Street, LV-1004, Riga, Latvia; Institute of Biology, University of Latvia, 3 Miera Street, LV-2169, Salaspils, Latvia.

\section{Отражает ли геометрическая и линейная морфометрия мозга дивергенцию в группе "guentheri” (Arvicolinae, Sumeriomys)?}

\section{Т.А. Зоренко*, У.Э. Кагайнис, Л.В. Барашкова}

РЕЗЮМЕ. Целью данной работы является исследование дивергенции размера и формы мозга трех таксонов полевок группы “guentheri” с использованием геометрического и линейного морфометрического анализа. Полученные данные показывают, что фактор пола не влияет на линейные параметры и форму мозга изучаемых таксонов, что свидетельствует о слабом влиянии полового отбора на морфологическую адаптацию и изменчивость структуры мозга. Линейные измерения исследуемых таксонов существенно различаются по всем признакам (24 параметра). Полученные данные свидетельствуют о глубоком расхождении Microtus guentheri от M. h. lydius и M. h. hartingi (92\%), что, очевидно, связано с более древней изоляцией этого вида в результате образования горного хребта Анатолийской диагонали. Различия между двумя подвидами (M. hartingi hartingi и M. h. lydius) значительно меньше - 63\%. Следует отметить, что полевка, обитающие в горах Странджа - M. $h$. strandzensis отличается от M. h. hartingi и M. h. lydius значительно больше — 82 и 75\% соответственно.

\footnotetext{
* Corresponding author
} 


\begin{abstract}
Эти различия могут отражать историю расселения полевок из Анатолии в Европу. Обнаружены также геометрические изменения мозга у всех таксонов. Анализ канонических вариаций показал, что все три таксона значительно различаются как в латеральном, так и в дорзальном направлении. Сравнение мозга сбоку у трех таксонов показало, что мозг $M$. h. lydius более плоский, чем M. h. hartingii, тогда как M. guentheri имеет более широкий мозг и более гладкий внешний обонятельный тракт, а также более мелкие обонятельные луковицы. С дорсальной стороны наблюдается деформация мозга M. guentheri в местах прикрепления полушария мозжечка к полушарию головного мозга, в то время как червь мозжечка у $M . h$. lydius более уплощен. Факторы, влияющие на разнообразие строения мозга, могут включать аллометрию, филогению и естественный отбор. Ускоренная морфологическая эволюция полевок группы “guentheri” может быть объяснена фрагментацией ареала и биотопов.
\end{abstract}

КЛЮЧЕВЫЕ СЛОВА: геометрическая морфометрия, структуры головного мозга, величина и форма мозга, морфологическая дивергенция, географическая изоляция, Microtus guentheri, Microtus hartingi.

\section{Introduction}

The "guentheri" group previously included one polytypic species - the Gunter's vole Microtus guentheri Danford et Alston, 1880 with a karyotype of $2 n=$ 54 (Golenishchev et al., 2002), which occupied a wide range from Israel, Lebanon, Syria to the Balkans and Africa (Niethammer \& Krapp, 1982; Musser \& Carleton, 2005; Gromov \& Erbaeva, 1995; Kryštufek \& Vohralik, 2005). The composition of the subspecies of the Gunter' vole is not precisely defined. Six-seven subspecies were noted, of which three in Europe (Gromov \& Polyakov, 1977). However, genetic molecular studies with the use of mt-cyt $b$ marker showed that $M$. guentheri is present in southeastern Anatolia, but in western Anatolia and Europe (Thrace) is Microtus hartingi Barret-Hamilton, 1903 (Kryštufek et al., 2009; Thanou et al., 2012). Both species are isolated from each other by a mountain range (Anatolian diagonal) (Yiğit \& Çolak, 2002).

M. hartingi lives in central and northwestern Anatolia and the Balkans. However, populations from Thrace and western Anatolia have long been isolated. The Straits of Dardanelle and the Bosporus were formed in the late Pliocene about two million years ago (Çağatay et al., 2000; Yaltırak et al., 2000), and some authors believe that the strains closed the gene flow between Asia and Europe, and the species formation has intensified (Yigit \& Çolak, 2002; Yiğit et al., 2012).

The status of voles from Europe is still not clearly defined. According to molecular data, there is no reason for the European populations of $M$. hartingi to consider as an independent species (Yiğit et al., 2017). However, the history of settlement and the formation of the M. harting $i$ range in Europe indicates the specificity of the existence of populations under conditions of fragmented habitats (Kryštufek et al., 2018), which could affect both the morphological and behavioural characteristics of European populations.

Significant differences in the morphology of the voles from western Anatolia and Thrace were found. Based on differences in back colouration, the shape of the baculum, and some exterior features, a number of authors suggested that southeastern populations could be considered as an endemic species of western Anatolia. M. lydius Blackler, 1916 differs from $M$. hartingi from southeastern Thrace (Bulgaria and European Turkey) (Yiğit \& Çolak, 2002; Yiğit et al., 2012; Markov et al., 2014). Differences in the linear parameters of sperm (Zorenko \& Golenishchev, 2015) and cytogenetic differences between these populations also were found (Zima et al., 2013). At the molecular level, differences between voles from Anatolia and Thrace were also identified: the index of nucleotide diversity and number of mutations in the three genes (mt-co1, mt-cyt $b, 12 \mathrm{~S}$ rRNA) of $M$. hartingi from Thrace are very low in comparison to a higher values of these indicators in the voles from western Anatolia (Cetintürk, 2018).

Hybridization of voles from Anatolia and Thrace revealed a high level of male sterility. Although F1 hybrids are quite viable and can breed, their descendants (F2 and backcross) are often unviable, subvital, semi-sterile or sterile, which is the result of a "hybrid breakdown" (Zorenko et al., 2016).

The brain is the important structure of animals. The brain has been studied in many mammalian species (Belenkov \& Goreva, 1969; Khrustaleva et al., 1994; Voino, 1994; Zorenko, 2013), but relatively few studies have been devoted to a group of closely related species and genera (Kovalenko, 1982). The results of investigations of the external structure of the brain were used in functional morphology (Andreeva \& Obukhov, 1999; Bruner et al., 2012, 2014), as well as in systematic (Zorenko, 2013) and evolutionary studies (Bruner, 2004). In this regard, not only linear measurements but also geometric morphometrics to describe morphological variation of various indices can be used (Pavlinov \& Mikeshina, 2002; Barčiovà, 2009; Voyta et al., 2013; Kamilari et al., 2013; Gorodilova \& Vasilyeva, 2014). Physicians (Boyagina et al., 2016) and anthropologists (Bruner, 2004; Bruner et al., 2012, 2014) show the considerable attention to the study of geometric morphometric of the brain. The brain size and shape may have played a relevant role in human brain evolution (Bruner et al., 2010). Therefore, using of the brain in study of closely related species of rodents can open up new perspectives in understanding of their evolution.

The purpose of this work is to investigate the divergence of the brain' size and shape of three taxa of "guentheri" voles group using linear and geometric morphometric analysis. 


\section{Material and methods}

This work was carried out using the collection of animals from the Laboratory of Ethology (University of Latvia). The voles, in total $60\left(\mathrm{~F}_{1}-\mathrm{F}_{7}\right.$ generations, aged 6-7 months) were collected from three different locations (Fig. 1). Each location represented one taxon of the "guentheri" group: M. guentheri $(4 q$ and $8 \delta$ from Türkoğlu/ Kahramanmaraş, Turkey), M. h. hartingi (12 + and $12 \curvearrowright$ from Rhodope Mountains, Bulgaria), and M. h. lydius (12 $\bigcirc$ and $12 \delta$ from the vicinity of Kirşehir, Turkey). We accept that the voles from the Rhodope belong to the $M$. $h$. hartingi subspecies, since they border on the Greek populations. Earlier we performed linear morphometry of $M$. h. strandzensis (Zorenko, 2013); however, a comparison was made with taxa of the "socialis" group. Therefore, in this study we used data on this subspecies for comparison with taxa of the "guentheri" group.

The conditions of keeping and working with animals were compiled in accordance with standards of Council of the European Communities 86/609/EES. Animals were sacrificed by cervical dislocation, which is regarded as a humane method for small rodents (FELASA, certificate C-category). The skull with the brain was placed in neutral $10 \%$ formalin (for 10 days). Then the brain was removed from the skull and fixed in formalin.

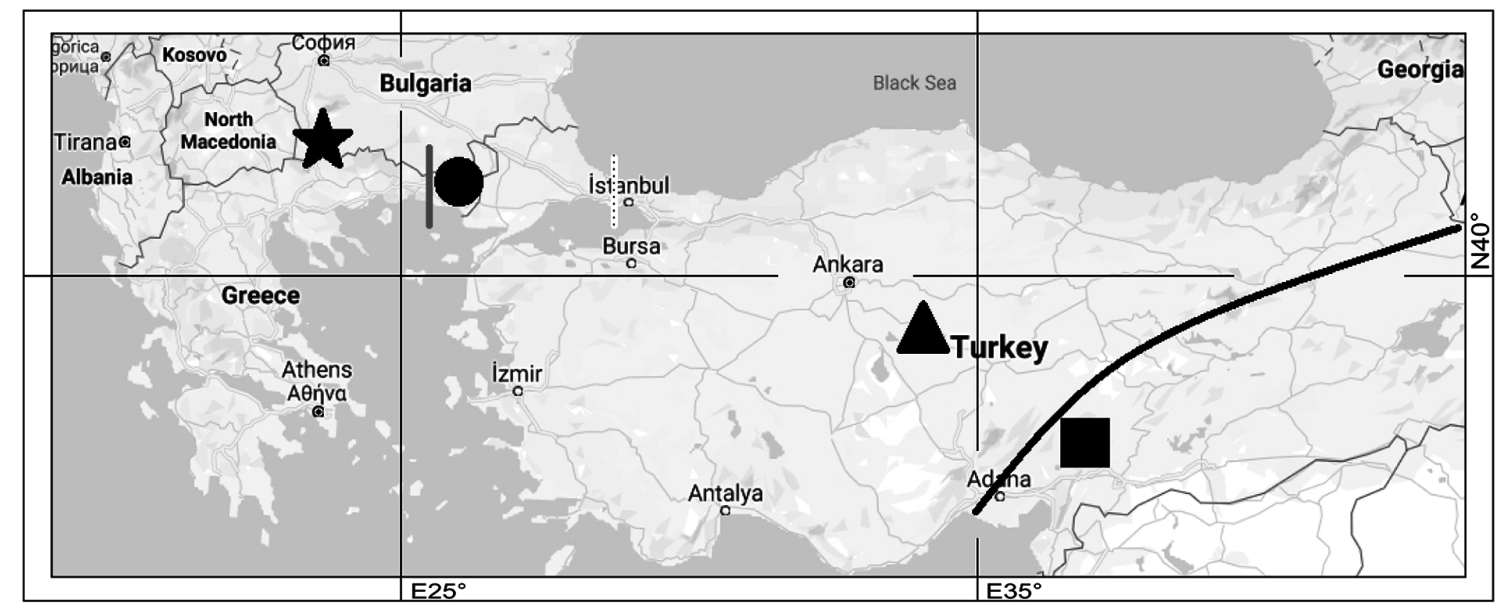

Fig. 1. "Guentheri” group taxa studied locations: star - Rhodope (M. h. hartingi), circle — (M. h. strandzensis) (Zorenko, 2013), triangle - western Anatolia (M. h. lydius), square - southeastern Anatolia (M. guentheri). The barrier of isolation is marked with lines: black line - Anatolian Diagonal, white dotted line - Bosporus Strait, grey line - Maritsa River.

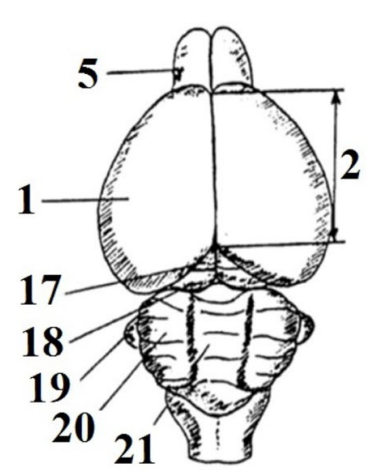

A

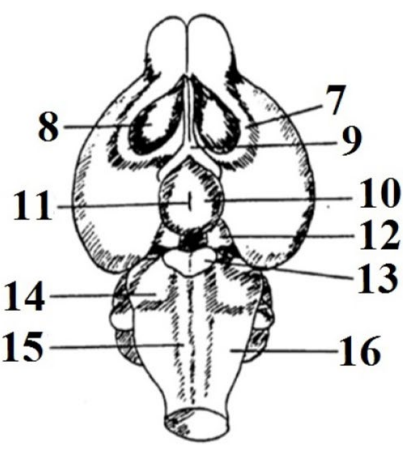

B

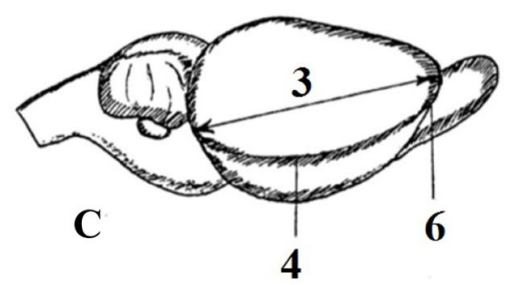

\section{Linear and weight measurements}

Brain and olfactory bulbs and cerebellum were weighted $( \pm 0.01 \mathrm{mg})$ after kept air dry for 5 minutes. Measurements were taken using a digital calliper ( $\pm 0.1 \mathrm{~mm}$ ): length, width and height of the brain; length and width of olfactory bulbs; hemispheres medial and lateral length, length, width and square of pons (pons Varolii) and trapezoid body; optical tubercles and acoustical tubercles of corpora guadrigemina, and finally, width of cerebellum with flocculonodular lobes (Fig. 2). The cephalization index (brain mass square relation to body

Fig. 2. Schematic illustration of vole brain structure and measurements assessed on its anatomical parts in dorsal view (A), ventral view (B) and lateral view (C): 1 - cerebral hemisphere, 2 - hemispheres medial length, 3 - hemispheres lateral length, 4 - rhinal gyrus, 5 - olfactory bulbs, 6 external olfactory tracts, 7 - olfactory gyrus, 8 - olfactory tubercles, 9 - optic hiasm, 10 - tuber cinereous, 11 hypothalamus, 12 - cerebral peduncles, 13 - pons varolii, 14 - trapezoid body, 15 - striate parapyramidales, 16 medulla oblongata, 17 - optical tubercles, 18 - acoustical tubercles of corpora guadrigemina, 19 - flocculonodular lobes, 20 - cerebellum hemisphere, 21 - cerebellum vermis. 
mass $\times 100$ ) was also calculated. In total, 24 parameters were characterized.

The mean value and errors were calculated for all measurements of brain parameters; pairwise comparisons between taxa were performed by using Wilcoxon test (RStudio 3.5.0). We accepted the level of significance at $p<0.05$.

\section{Microscopy}

Brains with optically visible mechanical damage were disclosed from the further manipulations before GM. Brains of 31 vole individual (Tab. 1) were observed in Leica MSV266 stereomicroscope. Pictures were photographed using a digital camera operated by the software Leica Application Suite, ver. 1.06d. Brains were air dried for 5 minutes on the filter paper before photographed to avoid reflection of light occurring in wet regions of the surface. Afterwards, each brain was fixed on the depression (depth $-2 \mathrm{~mm}$ ) of a movable polystyrene plate $(100 \mathrm{~mm}$ width $/ 100 \mathrm{~mm}$ length $/ 10 \mathrm{~mm}$ height). The magnification of 0.65 times was used and appropriate focus was set for each specimen. Equal view and parameters (height, angles of precise dorsal or lateral projecting and the magnification of $65^{\times}$) were used among all brain samples photographed. Taxon, sex, position (lateral or dorsal) and the three-digit code of the individual ID were coded in the name for each picture and file was saved in the tiff format (digital resolution - 2560/1920 pixels).

Geometric morphometrics and shape analysis

The 23 landmarks from the lateral and 22 landmarks from the dorsal side (Fig. 3, Tab. 2) were digitized by tpsDig32 (Rohlf, 2016). Lateral and dorsal projections were used as two different datasets. In the case of the dorsal projection, several landmarks $(1,11,14,15,22)$ were disclosed from the analysis due to a significant number of missing landmark points among the dataset. Taxa and sex were treated as variables (individuals or factors). MorphoJ (Klingenberg, 2011) was used to perform Generalized Procrustes Analysis (GPA), Principal Component Analysis (PCA), Canonical Variance Analysis (CVA) and Discriminant Function Analysis (DFA).

\section{Results}

\section{Size differences}

The effect of sex on the length of the brain is not very pronounced. All linear and weight parameters showed no statistic differences $(p>0.1)$. The obtained results allowed combining the females and males data in one sample, characterizing the taxon for brain size.

Three taxa of voles differ significantly in both weight and linear parameters (Tab. 3). Among the studied taxa, the number of statistically significant differences ranged from 16 to 23 (out of 24 studied). The most significant differences were noted between $M$. guentheri compared and $M$. hartingi - by 22-23 parameters. The level of differences between the two subspecies of $M$. hartingi is lower (16 parameters) (Fig. 4).

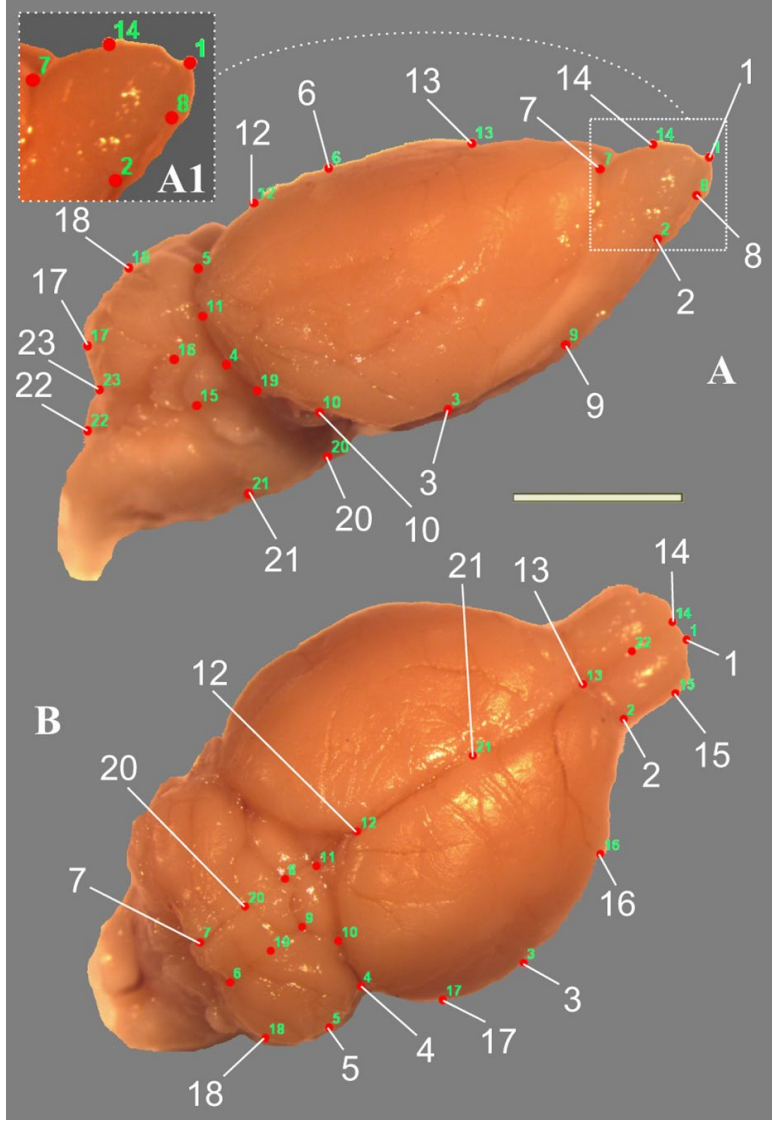

Fig. 3. The landmark locations pointed with red dots (scale bar: $5 \mathrm{~mm}$ ); A: lateral projection of brain (A1 - magnified part of the brain with landmarks position and symbols size like on a screen of tpsDIG; green numbers indicate landmark numbers), B: dorsal projection of brain. The white numbers correspond to the landmarks.

Table 1. Characteristics of the sample sizes per each dataset used in the statistical analysis, among various taxa of "guentheri" group (number of disclosed brains during statistical analysis of geometric morphometrics are indicated in brackets).

\begin{tabular}{|l|c|c|c|c|c|c|}
\hline \multirow{3}{*}{ Taxa } & \multicolumn{4}{|c|}{ Number of brain specimens } \\
\cline { 2 - 8 } & \multicolumn{3}{|c|}{ lateral projection } & \multicolumn{2}{c|}{ dorsal projection } \\
\cline { 2 - 7 } & $\begin{array}{c}\text { fe- } \\
\text { males }\end{array}$ & males & total & $\begin{array}{c}\text { fe- } \\
\text { males }\end{array}$ & males & total \\
\hline M. h. hartingi & $6(2)$ & $7(2)$ & $13(4)$ & $6(1)$ & $7(1)$ & $13(2)$ \\
\hline M. guentheri & $3(1)$ & 3 & 6 & 3 & $3(2)$ & $6(2)$ \\
\hline M. h. lydius & 6 & $6(1)$ & $12(1)$ & $6(1)$ & $6(1)$ & $12(2)$ \\
\hline Total & \multicolumn{3}{|c|}{$31(5)$} & \multicolumn{3}{c|}{$31(6)$} \\
\hline
\end{tabular}

\section{Shape differences}

Procrustes ANOVA test confirmed significant difference in the size (as centroid size) and shape of both dorsal and lateral projections between the three 
Table 2. Anatomical and mathematical landmarks used to asses geometric morphometrics of brain of "guentheri" group voles (semi-landmarks or so-called mathematical landmarks indicated with the asterisk *).

\begin{tabular}{|c|c|c|}
\hline \multirow{2}{*}{$\begin{array}{c}\text { Land- } \\
\text { mark } \\
\text { number }\end{array}$} & \multicolumn{2}{|c|}{ Description of landmark location } \\
\hline & Lateral projection & Dorsal projection \\
\hline 1 & Point of terminal tip of olfactory bulbs (apical position) & Point of terminal tip of olfactory bulbs (marginal position) \\
\hline 2 & $\begin{array}{l}\text { Transition point between olfactory bulbs and external } \\
\text { olfactory tracts }\end{array}$ & $\begin{array}{l}\text { Transition point between olfactory bulbs and hemisphere } \\
\text { (marginal position) }\end{array}$ \\
\hline 3 & $\begin{array}{l}\text { Point of maximum height in cerebral hemisphere main axis } \\
\text { (basal position) }\end{array}$ & $\begin{array}{l}\text { Point of maximum width in cerebral hemisphere main } \\
\text { axis (marginal position) }\end{array}$ \\
\hline 4 & $\begin{array}{l}\text { Point of maximum length of hemisphere main axis (frontal } \\
\text { position) }\end{array}$ & $\begin{array}{l}\text { Point of maximum length of hemisphere main axis } \\
\text { (marginal position) }\end{array}$ \\
\hline 5 & $\begin{array}{l}\text { Transition point between cerebellum and cerebral hemi- } \\
\text { sphere }\end{array}$ & $\begin{array}{l}\text { Point of maximum width of cerebellum_main axis } \\
\text { (marginal position) }\end{array}$ \\
\hline 6 & $\begin{array}{l}\text { Point of maximum height in cerebral hemisphere main axis } \\
\text { (apical position) }\end{array}$ & $\begin{array}{l}\text { Transition point between vermis and hemisphere } \\
\text { (frontal position) }\end{array}$ \\
\hline 7 & $\begin{array}{l}\text { Transition point between olfactory bulbs and cerebral hemi- } \\
\text { sphere (frontal position) }\end{array}$ & $\begin{array}{l}\text { Transition point between left and right cerebellum hemi- } \\
\text { sphere (frontal position) }\end{array}$ \\
\hline 8 & Point at half of the distance between landmarks 1 and $2 *$ & $\begin{array}{l}\text { Transition point between vermis and acoustical tubercles } \\
\text { of corpora guadrigemina (medial position) }\end{array}$ \\
\hline 9 & Point at half of the distance between landmarks 2 and $3 *$ & $\begin{array}{l}\text { Transition point between vermis and acoustical tubercles } \\
\text { of corpora guadrigemina (marginal position) }\end{array}$ \\
\hline 10 & Point at half of the distance between landmarks 3 and $4 *$ & $\begin{array}{l}\text { Transition point between cerebellum and acoustical } \\
\text { tubercles of corpora guadrigemina (apical position) }\end{array}$ \\
\hline 11 & Point at half of the distance between landmarks 4 and $5 *$ & $\begin{array}{l}\text { Transition point between left and right acoustical } \\
\text { tubercles of corpora guadrigemina (frontal position) }\end{array}$ \\
\hline 12 & Point at half of the distance between landmarks 5 and $6 *$ & $\begin{array}{l}\text { Transition point between left and right cerebral hemi- } \\
\text { sphere (frontal position) }\end{array}$ \\
\hline 13 & Point at half of the distance between landmarks 6 and $7 *$ & $\begin{array}{l}\text { Transition point between olfactory bulbs and cerebral } \\
\text { hemisphere (medial position) }\end{array}$ \\
\hline 14 & Point at half of the distance between landmarks 1 and $7 *$ & $\begin{array}{l}\begin{array}{l}\text { Transition point between left and right olfactory bulbs } \\
\text { (caudal position) }\end{array} \\
\end{array}$ \\
\hline 15 & $\begin{array}{l}\text { Point of paraflokuluss attachment to cerebellum (basal } \\
\text { position) }\end{array}$ & Point at half of the distance between landmarks 1 and $2 *$ \\
\hline 16 & $\begin{array}{l}\text { Point of paraflokuluss attachment to cerebellum (apical } \\
\text { position) }\end{array}$ & Point at half of the distance between landmarks 2 and $3 *$ \\
\hline 17 & $\begin{array}{l}\text { Point of maximum height in cerebellum main axis (frontal } \\
\text { position) }\end{array}$ & Point at half of the distance between landmarks 3 and $4 *$ \\
\hline 18 & $\begin{array}{l}\text { Point of maximum height in cerebellum main axis (apical } \\
\text { position) }\end{array}$ & Point at half of the distance between landmarks 5 and $6 *$ \\
\hline 19 & Transition point between cerebellum and medulla & Point at half of the distance between landmarks 6 and $9 *$ \\
\hline 20 & Point of the insertion of trapezoid body (basal position) & Point at half of the distance between landmarks 7 and $8 *$ \\
\hline 21 & Point of terminal tip of trapezoid body (marginal position) & Point at half of the distance between landmarks 12 and $13 *$ \\
\hline 22 & $\begin{array}{l}\text { Point of the terminal tip of the visible part of cerebellum } \\
\text { vermis (basal position) }\end{array}$ & $\begin{array}{l}\text { Point at half of the distance between landmarks } \\
13 \text { and } 14^{*}\end{array}$ \\
\hline 23 & $\begin{array}{l}\text { Point of the terminal tip of the visible part of cerebellum } \\
\text { vermis (apical position) }\end{array}$ & \\
\hline
\end{tabular}

taxa. However, there was no significant difference in the shape of the brain between males and females and the centroid size was registered significantly different between males and females only in dorsal projected images of investigated $M$. hartingi and M. guentheri vole brains (Tab. 4).

In PCA analysis, the first two PCs explained $46.72 \%$ of morphological variation for data of lateral projection, from which the PC1 explained $30.42 \%$ of variability. Similarly, data of morphological variation in dorsal projection were explained by $43.79 \%$ variation by first two PCs, from which the PC1 explained $24.23 \%$ of data variance. Samples were relatively separately distributed among PC1 and PC2 axes for both lateral (Fig. 5A, left) and dorsal (Fig. 5B, left) projections in the PCA plots. However, the shape difference between the three 


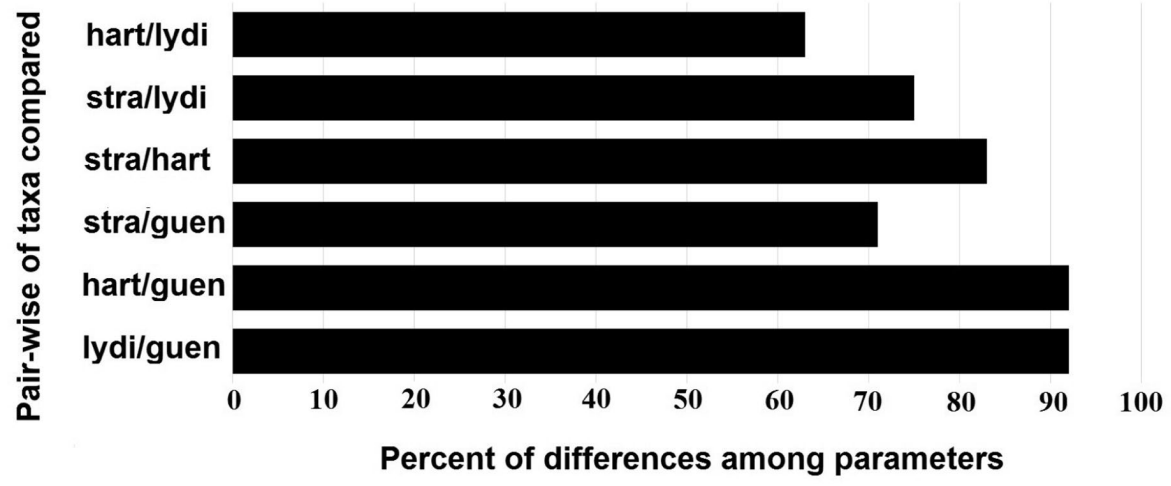

Fig. 4. Differences in linear and weight parameters of brain's structure in percent. Symbols: lydi M. h. lydius, hart - M. h. hartingi, stra - M. h. strandzensis (Zorenko, 2013), guen - M. guentheri.
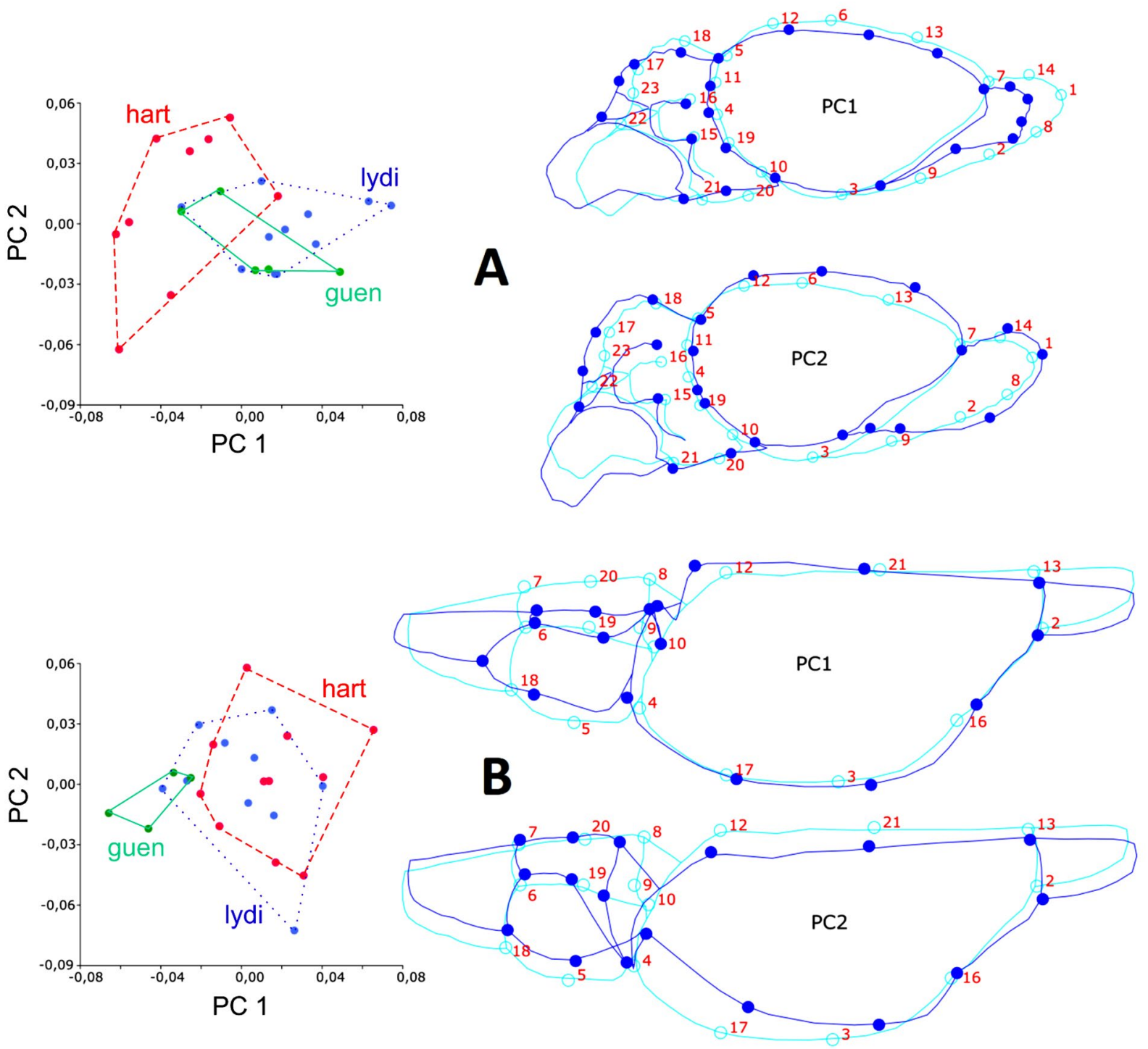

Fig. 5. Scatter plots of PCA (on left) and positive directional shape changes of PC1 and PC2 (on right) of lateral (A) and dorsal (B) projections among of three vole taxa of "guentheri" group (abbreviations see in Fig. 4). Blue dots indicate landmarks after shape deformation; red numbers indicate landmark numbers; scale factor for deformation visualisation -1.5 . 
Table 3. The main mean linear and mass parameters of the vole brain.

\begin{tabular}{|c|c|c|c|}
\hline Parameters & M. h. lydius & M. h. hartingi & M. guentheri \\
\hline Brain mass, $g$ & $0.82 \pm 0.01$ & $0.87 \pm 0.01$ & $0.57 \pm 0.01$ \\
\hline Cephalization index & $1.3 \pm 0.41$ & $1.5 \pm 0.51$ & $0.9 \pm 0.07$ \\
\hline Brain height, mm & $7.1 \pm 0.10$ & $7.5 \pm 0.11$ & $6.5 \pm 0.11$ \\
\hline Brain length, mm & $21.4 \pm 0.12$ & $21.3 \pm 0.21$ & $19.1 \pm 0.33$ \\
\hline Brain width, mm & $11.6 \pm 0.09$ & $11.6 \pm 0,11$ & $9.9 \pm 0,17$ \\
\hline Hemispheres lateral length, mm & $11.4 \pm 0.07$ & $11.0 \pm 0.10$ & $9.6 \pm 0.10$ \\
\hline Hemispheres medial length, mm & $8.4 \pm 0.08$ & $8.7 \pm 0 / 08$ & $7.3 \pm 0.10$ \\
\hline Olfactory bulbs length, $\mathrm{mm}$ & $3.1 \pm 0.08$ & $3.4 \pm 0.07$ & $2.7 \pm 0.14$ \\
\hline Olfactory bulbs width, $\mathrm{mm}$ & $3.3 \pm 0.09$ & $3.7 \pm 0.09$ & $3.0 \pm 0.12$ \\
\hline Olfactory bulbs mass, mg & $22.1 \pm 1.18$ & $24.9 \pm 0.97$ & $14.9 \pm 0.67$ \\
\hline Cerebellum width with flocculonodular lobes, $\mathrm{mm}$ & $9.2 \pm 0.08$ & $9.2 \pm 0.10$ & $8.1 \pm 0.23$ \\
\hline Cerebellum mass, $\mathrm{g}$ & $0.11 \pm 0.003$ & $0.11 \pm 0.002$ & $0.07 \pm 0.003$ \\
\hline Optical tubercles of corpora guadrigemina, length, $\mathrm{mm}$ & $2.3 \pm 0.05$ & $2.1 \pm 0.04$ & $2.0 \pm 0.02$ \\
\hline Optical tubercles of corpora guadrigemina, width, mm & $4.5 \pm 0.06$ & $4.2 \pm 0.06$ & $3.7 \pm 0.07$ \\
\hline Optical tubercles of corpora guadrigemina, area, $\mathrm{mm}^{2}$ & $10.3 \pm 0.25$ & $8.8 \pm 0.22$ & $7.4 \pm 0.07$ \\
\hline Acoustical tubercles of corpora guadrigemina, length, $\mathrm{mm}$ & $1.7 \pm 0.03$ & $1.6 \pm 0.03$ & $1.2 \pm 0.02$ \\
\hline Acoustical tubercles of corpora guadrigemina, width, mm & $5.2 \pm 0.06$ & $4.6 \pm 0.06$ & $4.2 \pm 0.13$ \\
\hline Acoustical tubercles of corpora guadrigemina, area, $\mathrm{mm}^{2}$ & $8.6 \pm 0.21$ & $7.5 \pm 0.17$ & $5.2 \pm 0.20$ \\
\hline Trapezoid body length, $\mathrm{mm}$ & $1.7 \pm 0.03$ & $1.6 \pm 0.04$ & $1.5 \pm 0.08$ \\
\hline Trapezoid body width, $\mathrm{mm}$ & $4.9 \pm 0.06$ & $5.0 \pm 0.06$ & $4.1 \pm 0.09$ \\
\hline Trapezoid body area, $\mathrm{mm}^{2}$ & $8.2 \pm 0.15$ & $7.9 \pm 0.22$ & $6.1 \pm 0.36$ \\
\hline Pons length, mm & $1.6 \pm 0.02$ & $1.7 \pm 0.04$ & $1.4 \pm 0.06$ \\
\hline Pons width, mm & $3.8 \pm 0.07$ & $3.9 \pm 0.10$ & $3.2 \pm 0.09$ \\
\hline Pons area, $\mathrm{mm}^{2}$ & $5.9 \pm 0.13$ & $6.6 \pm 0.23$ & $4.7 \pm 0.20$ \\
\hline
\end{tabular}

Table 4. Procrustes ANOVA results (F — Goodal's F, CS — centroid size, significant difference marked in bold).

\begin{tabular}{|c|c|c|c|c|c|c|c|c|c|}
\hline Individuals & Dataset & & $\mathrm{F}$ & $p$-value & Individuals & Dataset & & $\mathrm{F}$ & $p$-value \\
\hline \multirow{4}{*}{ Taxa } & \multirow{2}{*}{ Dorsal } & $\mathrm{CS}$ & 40.99 & $<0.0001$ & \multirow{4}{*}{ Sex } & \multirow{2}{*}{ Dorsal } & CS & 5.41 & 0.0292 \\
\hline & & Shape & 2.11 & $<0.0001$ & & & Shape & 1.21 & 0.2087 \\
\hline & \multirow{2}{*}{ Lateral } & $\mathrm{CS}$ & 38.38 & $<0.0001$ & & \multirow{2}{*}{ Lateral } & CS & 1.46 & 0.2394 \\
\hline & & Shape & 2.75 & $<0.0001$ & & & Shape & 0.82 & 0.7891 \\
\hline
\end{tabular}

"guentheri" group taxa (Fig. 5A and B, right) was similar to that calculated by CVA plots and is explained in the further text.

Samples of all taxa significantly differed in shape for both lateral and dorsal projection according to permutation $\mathrm{p}$ values based on Mahalanobis distance in CVA. According to permutation $p$ values based on Procrustes distance, significant difference in shape was registered only between taxa of $M$. guentheri and $M$. h. hartingi and between taxa of $M$. guentheri and
M. h. lydius for dorsal projections (Tab. 5) as well as only between taxa of $M$. $h$. lydius and $M$. h. hartingi for lateral projections (Tab. 5).

Results of DFA analysis also showed no statistically significant difference in shape between males and females for both lateral and dorsal projections (Tab. 6). However, during DFA several testing values proved that in both lateral and dorsal projections the shape deformation is significantly high among compared vole taxa (Tab. 7). 
Shape differences (deformation) between the mentioned taxa were also well separated along first axis of the scatter plot of CVA (Fig. 6). In CVA, the CV1 for dorsal projection explain $74.62 \%$, and CV1 for lateral projection $-76.40 \%$ of the total variation of shape among the three taxa. Most significant shape changes of the positive and negative directional deformation according to CV1 were the prolongation of olfactory bulbs, thickening of flocculonodular lobes and thickening of cerebral hemispheres for lateral projections (Fig. 6A) as well as the thickening of cerebellum hemisphere for dorsal projections (Fig. 6B) between the taxa $M$. guentheri and $M$. $h$. hartingi. Olfactory bulbs in samples of $M$. h. hartingi were more elongated anteriorly compared to $M$. h. guentheri that had shorter olfactory bulbs (Fig. 6A). Likewise, shortening of olfactory bulbs and prolongation of cerebral hemispheres for lateral projections between the taxa $M . h$. hartingi and $M . h$. lydius were the most significant shape changes according to CV1 (Fig. 6C).
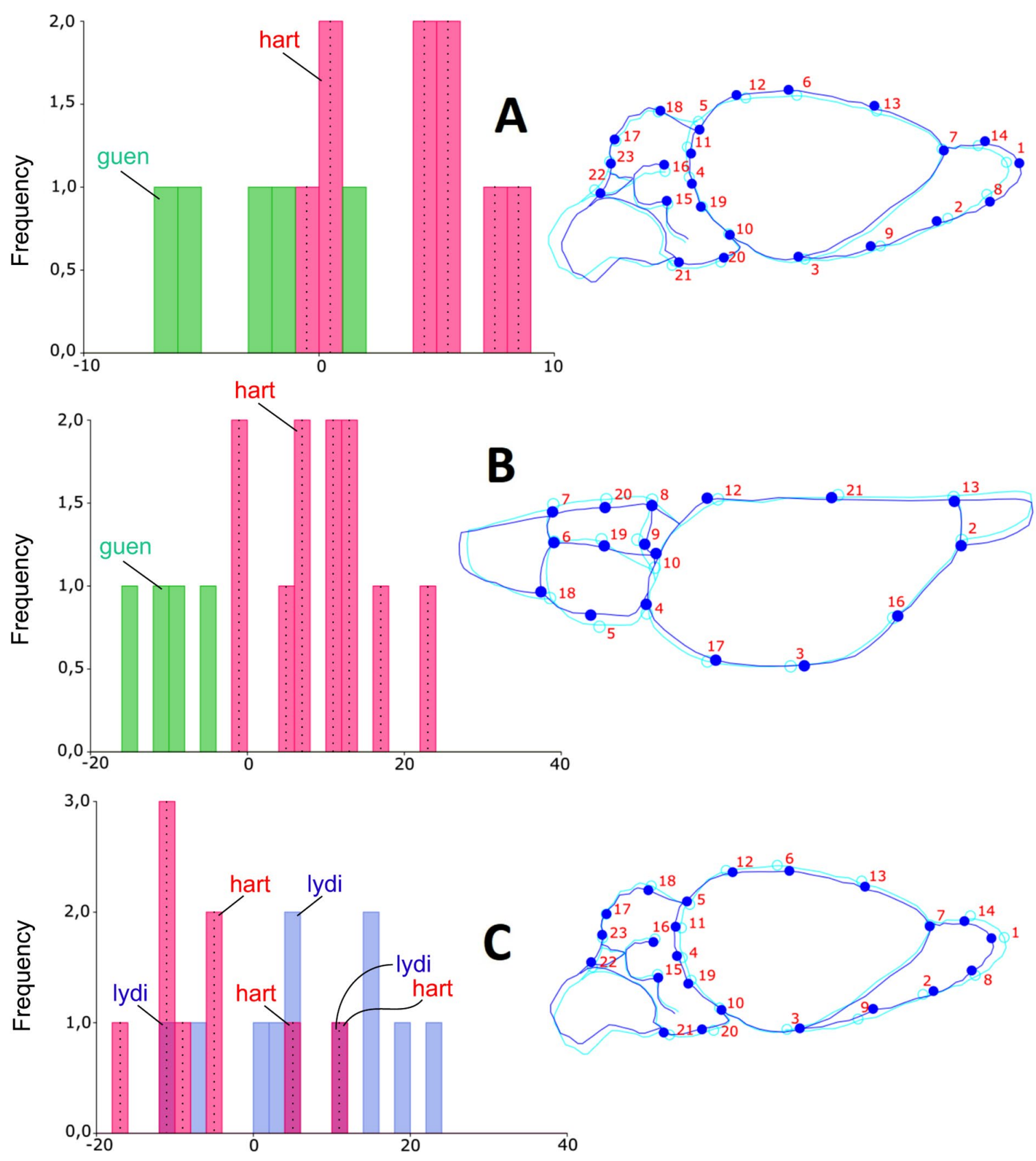

Fig. 6. DFA histogram (left) and CVA shape deformation results for lateral (A, C) and dorsal (B) projections (right) of three vole taxa of "guentheri" group (abbreviations see in Fig. 4). Blue dots indicate landmarks after shape deformation; red numbers indicate landmark numbers; scale factor for deformation visualisation - 1.0. 
Table 5. CVA results for lateral and dorsal projections (Mah. Dist. — Mahalanobis distance; Proc. Dist. — Procrustes distance; Perm. p — permutation p value; bold — statistically significant difference).

\begin{tabular}{|l|c|c|c|c|c|c|c|c|}
\hline \multicolumn{1}{|c|}{ Groups } & \multicolumn{7}{c|}{ M. guentheri } & \multicolumn{7}{c|}{ M. hartingi } \\
\hline & Mah.dist. & Perm.p. & Proc.dist. & Perm.p. & Mah.dist. & Perm.p. & Proc.dist. & Perm.p. \\
\hline \multicolumn{8}{|c|}{ Lateral projection } \\
\hline M. h. hartingi & 4.1625 & $\mathbf{0 . 0 0 2 2}$ & 0.0516 & 0.0539 & - & - & - & - \\
\hline M. h. lydius & 4.7956 & $\mathbf{0 . 0 0 0 4}$ & 0.0360 & 0.1308 & 5.5188 & $<\mathbf{0 . 0 0 0 1}$ & 0.0592 & $\mathbf{0 . 0 0 0 5}$ \\
\hline \multicolumn{8}{|c|}{ Dorsal projection } \\
\hline M. h. hartingi & 7.7251 & $<\mathbf{0 . 0 0 0 1}$ & 0.0625 & $\mathbf{0 . 0 0 1 2}$ & - & - & - & - \\
\hline M. h. lydius & 6.8804 & $\mathbf{0 . 0 0 0 1}$ & 0.0511 & $\mathbf{0 . 0 2 0 5}$ & 3.5722 & $<\mathbf{0 . 0 0 0 1}$ & 0.0301 & 0.2346 \\
\hline
\end{tabular}

Table 6. DFA results for lateral and dorsal projections among vole sexes (T2 — T-square; Param. $\mathrm{p}$ — parametric $\mathrm{p}$ values; Perm. $\mathrm{p}$ — permutation $\mathrm{p}$ value; Proc. — Procrustes distance value; bold — significant difference).

\begin{tabular}{|l|c|c|c|c|}
\hline & \multicolumn{4}{c|}{ Females } \\
\hline & T2 & Param.p. & Perm.p. (T2) & Perm.p. (Proc.) \\
\hline \multicolumn{5}{|c|}{ Lateral projection } \\
\hline Males & 41.0745 & 0.9984 & 0.5700 & 0.5910 \\
\hline \multicolumn{6}{|c|}{ Dorsal projection } \\
\hline Males & 78.0953 & 0.9841 & 0.7190 & 0.2490 \\
\hline
\end{tabular}

Table 7. DFA results for lateral and dorsal projections among different vole taxa (T2 - T-square; Param. $p$ - parametric $\mathrm{p}$ values; Perm. $\mathrm{p}$ — permutation $\mathrm{p}$ value; Proc. — Procrustes distance value; bold — significant difference).

\begin{tabular}{|c|c|c|c|c|c|c|c|c|}
\hline \multirow[t]{2}{*}{ Groups } & \multicolumn{4}{|c|}{ M. guentheri } & \multicolumn{4}{|c|}{ M. h. hartingi } \\
\hline & $\mathrm{T} 2$ & Param.p. & Perm.p. (T2) & Perm.p. (Proc.) & $\mathrm{T} 2$ & Param.p. & Perm.p. (T2) & $\begin{array}{l}\text { Perm.p. } \\
\text { (Proc.) }\end{array}$ \\
\hline \multicolumn{9}{|c|}{ Lateral projection } \\
\hline M. h. hartingi & 41.6041 & 0.9125 & 0.0150 & 0.0430 & - & - & - & - \\
\hline M. h. lydius & 33.9276 & 0.9693 & 0.0490 & 0.1350 & 108.5430 & 0.8988 & 0.0080 & $<0.0001$ \\
\hline \multicolumn{9}{|c|}{ Dorsal projection } \\
\hline M. h. hartingi & 91.2031 & 0.8034 & 0.0010 & 0.0020 & - & - & - & - \\
\hline M. h. lydius & 35.8342 & 0.9319 & 0.0900 & 0.0290 & 54.8047 & 0.9811 & 0.2730 & 0.2300 \\
\hline
\end{tabular}

\section{Discussion}

In order to use morphometry, especially the geometric method, it is important to exclude the possible impact of age and gender on certain structures (Barčiovà, 2009). The results of the linear morphometry show that sex dimorphism of voles is not pronounced. The male and female voles studied did not differ significantly with regard to the dorsal and ventral side of the brain in linear and geometric morphometry (Tabs 7 and 8). Apparently, sexual selection does not affect the parameters of the brain. This pattern has been demonstrated in many vole species of the Microtini tribe (Zorenko, 2013).
Age variability has a great influence on the size and shape of the morphological structure (Barčiovà, 2009; Voyta et al., 2013; Orbach et al., 2017). The vole's brain development finishes early in comparison with the growth of other organs (for example the skull), which reflects the general pattern of ontogenesis in mammals. The absolute and relative mass of the vole's brain increases rapidly especially in the age of 12 days to 20 days when intense brain maturing occurs. At this age, the vole's brain is ready to perceive the most important signals of the external environment and is able to ensure the formation of basic patterns of behaviour. Starting from the 20th day, brain growth slows down; its relative 
weight begins to decrease. Two months old voles do not differ from adults in the structure of the brain, as well as in the relative mass of the brain, which indicates the completion of its development. However, the absolute mass is still increasing. Thus, the allometric factor is very important. Therefore, for morphometric analysis, adult animals were taken, in which the growth of the body was complete.

During geometric morphometric analysis, we detected several shape differences between the three "guentheri" taxa (Tabs. 4, 5 and 7; see also Figs. 5 and $6)$. The prolongation of olfactory bulbs, thickening of flocculonodular lobes and thickening of cerebral hemispheres for lateral projections (Fig. 6A) as well as the thickening of cerebellum hemisphere for dorsal projections (Fig. 6B) were the most significant shape deformations between the taxa M. guentheri and $M . h$. hartingi (see also PC1 in Fig. 5A). Olfactory bulbs in samples of $M$. $h$. hartingi were more elongated anteriorly compared to $M$. guentheri that had shorter olfactory bulbs (Fig. 6A). Likewise, shortening of olfactory bulbs and prolongation of cerebral hemispheres for lateral projections between the taxa $M$. $h$. hartingi and $M . h$. lydius were the most significant shape changes according to PC1 (Fig. 5A) and CV1 (Fig. 6C).

Nevertheless, the geometric morphometric analysis was executed with relatively small sample sizes for each data sub-group $(2,3,6-13)$ which can conduct to the problem of low diversity of investigated individuals. In most cases that is not enough to characterize morphological diversity in the referenced taxa, yet commonly is seen in other similar published studies (Voyta et al., 2013; Kamilari et al., 2013; Orbach et al., 2017; Kaya et al., 2018).

All studied taxa differ noticeably in most linear parameters of the brain - the level of differences varies from 67 to $96 \%$ (Fig. 4). In M. guentheri, most of the parameters are not only different, but almost do not overlap with those of $M$. hartingi. A large number of brain signs overlap between the subspecies of $M$. hartingi, so the level of differences is reduced to $67 \%(M$. h. hartingi/ $M$. h. lydius) and $75 \%$ (M. h. strandzensis/M. h. lydius $)$ (see also Fig. 4). An exception is the $M$. h. hartingi subspecies, whose brain is heavier, longer and wider; the differences are noted in the mass and length of the bulbs, so the level of differences is already equal to $83 \%$.

We predicted that geographical location would influence the vole brain. Linear and geometric morphometric data indicate that individuals from different populations (especially for the three subspecies of M. hartingi) differ significantly (Fig.4, Tab. 3), which may depend on local ecological conditions, and they were supported by selection. Variability in brain size has been demonstrated in subspecies of Microtus socialis Pallas, 1779 (Zorenko, 2013). Perhaps a change in geometric patterns affects the value of the indices of the brain. A similar hypothesis for the sections of the brain cortex of Microtus arvalis Pallas, 1779 was expressed (Yaskin \& Lenec, 1996). Brain geometry is influenced by the volumetric proportions of its components, as well as by their spatial organization and patterns of connections (Bruner et al., 2014). Shape differences can be the result of changes in the relative position of neural elements of the brain and may have played a particularly relevant role in human brain (Bruner, 2004).

The vole brain size is highly variable within a species. Variability was shown in many mammal species too (Kovalenko, 1982; Khrustaleva et al., 1994; Zorenko, 2013). The analysis of brain size parameters provided the opportunity to prepare key tables to distinguish between genera and species of voles (Zorenko, 2013). Geometric morphometric analysis showed significant differences in the brain shape of voles as well. Therefore, we can talk about the important role of a phylogenetic signal.

Functional morphology may have a definite meaning. Thus, the dimensions of the optical tubercles and acoustical tubercles are associated with the degree of development of vision and hearing. In animals with more advanced vision, optical tubercles dominate; in more developed hearing, acoustical tubercles are dominated (Khrustaleva et al., 1994). However, this is a simplified view of the functions of the corpora guadrigemina. Optical tubercles play an important role in ensuring systemic reactions (eye movements, earlap, heads and vibrissae) and, therefore, they are one of the elements of integrative brain systems of mammals. An approximate reaction to the sound signal with the participation of the acoustical tubercles occurs (Andreeva \& Obukhov, 1999). The size of the olfactory bulbs depends on the nature of the food: in seed-eating species, they are larger than in green-eating ones.

As noted in the introduction, more recently, Gunther's vole, which has a large range, was considered as a single species (Musser \& Carleton, 2005; Kryštufek \& Vohralik, 2005). However, molecular (Kryštufek et al., 2009) and morphological (Yiğit \& Çolak, 2002; Yiğit et al., 2012; Markov et al., 2014; Zorenko \& Golenishchev, 2015) studies found evidences showed significant differences in all investigated populations, which could be a result of isolation of populations during the resettlement of voles from the centre of origin and the subsequent formation of the range.

Molecular evidence indicates that southwest Asia was the cradle for voles of the subgenus Sumeriomys Argyropulo, 1993 (Kryštufek et al., 2009), and this group was numerous in the fossils from the Early Pleistocene (Goren-Inbar et al., 2000) and later (Marder et al., 2011). In the same region, the formation of vole group "guentheri" took place (Yiğit et al., 2017). Prolonged isolation by the mountain Anatolian Diagonal of a part of the ancient population, which is close to $M$. h. lydius, contributed to the accumulation of differences, including morphological ones.

M. guentheri statistically reliably differs from $M$. hartingi in absolute mass of the brain and its separate parts (olfactory bulbs, cerebellum, and large hemispheres), as well as in most linear parameters of the brain (Fig. 4, Tab. 3). The brain of this taxon also differs in its shape (both frontally and laterally). The differences in linear and weight parameters of $M$. guentheri are 
explained by smaller brain sizes, while body size has little effect on brain size: the correlation of brain mass and body is only 0.09 ; brain length and body length 0.48 $(p<0.001)$. Significant differences in the brain compared with the three taxa of $M$. hartingi were noted for 22-23 indicators (Fig. 4).

The resettlement of voles to Europe and the subsequent isolation of new European populations from the maternal population of the Bosporus Strait led to their divergence. The formation of the $M$. hartingi range in Europe apparently occurred under conditions of fragmented habitats, which was determined by the influence of climate fluctuations in the Late Pleistocene and Holocene. Currently, separate fragments with different size (Kryštufek et al., 2018) represent the range. Fragmentation of friendly habitats and isolation from the original population could contribute to morphological divergence. Harting's vole probably colonized Europe (Kryštufek et al., 2018) from Anatolia through a land corridor that allowed fauna exchange between the regions from the Middle Pleistocene (McHugh et al., 2008). Finally, 7-5.3 thousand years ago the corridor was flooded with a significant rise in sea level (Kerey et al., 2004).

The emergence of the Bosporus Strait and the separation of part of the population in southern Europe also contributed to the morphological differences. The subspecies $M$. $h$. harting $i$ has the largest brain and olfactory bulbs. Brain length and width in $M . h$. hartingi and M. h. lydius are similar; however, the height is significantly greater. The ratio of the parameters of the hemispheres of this subspecies is changed: a large medial and a shorter lateral length. In total, there are sixteen differences in parameters out of 24 (67\%) (Fig. 4).

Another subspecies $M$. h. strandzensis, whose brain sizes also have significant differences, inhabits the southeastern part of the Balkans (Zorenko, 2013). $M . h$. strandzensis differs from $M$. h. lydius by 18 parameters $(75 \%)$, whereas from $M$. h. hartingi by $20(83 \%)$. It has been established that $M$. $h$. strandzensis olfactory bulbs are long and relatively narrow, whereas in the other two subspecies they are almost equal in both length and width. The cerebellum has the lowest mass $(92.8 \mathrm{mg}$, i.e., $12.5 \mathrm{mg}$ less than $M$. h. lydius and $M$. h. hartingi). In this taxon, the optical tubercles and acoustical tubercles have almost the same square, whereas in $M$. $h$. lydius the square of the optical tubercles is larger than the acoustical but in $M . h$. hartingi smaller.

The results obtained can be explained by the fact that the formation of the range took place over a long period and the degree of isolation between the three vole taxa (M. h. lydius, M. h. strandzensis and M. h. hartingi) is not the same. There is evidence that the Harting's vole settled Greece (Boeotia) from the Late Pleistocene to the Early Neolithic (Wilczyński et al., 2016). Perhaps the Rhodope vole population is connected with the Greek populations, forming one of the large fragments of the current range. It is possible that these are the most ancient populations. Therefore, $M . h$. hartingi is distinguished by a smaller divergence in the structure of the brain, as compared to $M$. h. lydius. In the region of the southeastern Balkans repeated colonization from Asia was possible, which affected less pronounced morphological differences between $M$. h. strandzensis and $M$. h. lydius (Thanou et al., 2012; Kryštufek et al., 2018).

In conclusion, it should be noted that M. guentheri is clearly isolated from the $M$. harting $i$ in size and shape of the brain, which is consistent with the data obtained on the structure of the skull, bacula, and spermatozoa, as well as the molecular characteristics of the species. Despite the similarity of molecular characteristics, the Harting's vole is not so uniform morphologically, which indicates an active process of morphological evolution and divergence in the Harting's vole. $M$. $h$. lydius is clearly isolated, and noticeable differences are found between $M$. h. hartingi and M. h. strandzensis. Evolutionary transformations of the shape of the brain could cause such significant changes in its linear parameters.

A high morphological divergence and accelerated evolutionary changes were noted for the $M$. hartingi of the fragmentation of habitats (Kryštufek et al., 2018). Morphological changes in response to fragmentation are similar to changes in island species (Millien, 2006, 2011). It has been shown that body size changes in 25 Danish mammals over the past two centuries have followed the island rule and were attributed to habitat fragmentation (Schmidt \& Jensen, 2003). The same factors as on the islands apparently were acting in the small fragmented populations of the Harting's vole in Europe. The main factor could be a decrease in habitat area, while the absence of predators, a decrease in interspecific competition and limitation of resources (Dayan \& Simberloff, 1998; Guthrie, 2003) apparently, did not act. Morphological divergence often occurs in relatively short periods, whereas molecular changes are more often associated with long periods. Therefore, the absence of correspondence between morphological and molecular evolution is possible.

ACKNOWLEDGEMENTS. We would like to express our great gratitude to researcher Dr. Fedor N. Golenishchev from the Zoological Institute of the Russian Academy of Sciences for providing the founders M. guentheri and M. h. lydius for our laboratory colony. We are grateful to the anonymous reviewers for the extensive comments and fruitful discussions of previous versions of the manuscript.

\section{References}

Andreeva N.G. \& Obukhov D.K. 1999. [Evolutionary morphology of vertebrate nervous system]. SaintPetersburg: Lana. 384 p. [in Russian].

Barčiovà L. 2009. Advances in insectivore and rodent systematics due to geometric morphometrics // Mammal Review. Vol.39. No.2. P.80-91.

Belenkov N.Yu. \& Goreva O.A. 1969. [The role of the hillocks of the tubercles of corpora guadrigemina in the exercise of the orienting reflex] // Zhurnal Vysshei Nervnoi Deyatelnosti. Vol.19. No.3. P.453-461 [in Russian]. 
Boyagina O.D., Kostilenko Ju.P., Mangov A.V. \& Inyutochkina I.A. 2016. [Linear metric parameters of individual variability of the corpus callosum sexual dimorphism of middle-aged people according to MRI scans] // Visnik Problem Biologii i Meditsini. Vol.1 (128). No.2. P.253-359 [in Russian, with English summary].

Bruner E. 2004. Geometric morphometrics and paleoneurology: brain shape evolution in the genus Homo // Journal of Human Evolution. Vol.47. P.279-303.

Bruner E., de la Cuétara J.M., Colom R. \& Martin-Loeches M. 2012. Gender-based differences in the shape of the human corpus callosum are associated with allometric variations // Journal of Anatomy. Vol.220. P.417-421.

Bruner E., de Lazaro G.R., de la Cuétara J.M., Martin-Loeches M., Colom R. \& Jacobs H.I. 2014. Midsagittal brain variation and MRI shape analysis of the precuneus in adult individuals // Journal of Anatomy. Vol.224. P.367-376.

Çağatay M.N, Görür N., Algan O., Eastoe C., Tchapalyga A., Ongan D., Kuhn T. \& Kuşçu I. 2000. Late Glacial-Holocene palaeoceanography of the Sea of Marmara: Timing of connections with the Mediterranean and the Black Seas // Marine Geology. Vol.167. P.191-206.

Çetintürk D. 2018. Mitochondrial DNA variations in Turkish Microtus hartingi (Barret-Hamilton 1903) and Microtus lydius (Blackler 1916) // Journal of Entomology and Zoology Studies. Vol.6. No.2. P.76-78.

Dayan T. \& Simberloff D. 1998. Size patterns among competitors: Ecological character displacement and character release in mammals, with special reference to island populations // Mammal Review. Vol.28. P.99-124.

Ellerman J.R. 1941. The Families and Genera of Living Rodents. Vol.2. London: British Museum (Natural History). 690 p.

Golenishchev F.N., Sablina O.V., Borodin P.M. \& Gerasimov S 2002. Taxonomy of voles of the subgenus Sumeriomys Argyropulo, 1993 (Rodentia, Arvicolinae, Microtus) // Russian Journal of Theriology. Vol.1. No.1. P.43-55.

Goren-Inbar N., Feibel C.S., Verosub K.L., Melamed Y., Kislev M.E., Tchernov E. \& Saragusti I. 2000. Pleistocene milestones on the out-of-Africa corridor at Gesher Benot Ya'aqov, Israel // Science. Vol.289. No.5481. P.944-947.

Gorodilova Ju.V. \& Vasilyeva I.A. 2014. [Geometric morphometrics of the low jaw of chromosomal dews of forehead mouse (Sylvaemus uralensis Pallas, 1881): taxonomical and ecological aspects] // Uspehi Sovremennogo Estestvoznaniya. No.11. P.19-24 [in Russian].

Gromov I.M. \& Erbayeva M.A. 1995. [The Mammals of Russia and Adjacent Territories. Lagomorphs and Rodents]. Saint-Petersburg: Zoologicheskii Institut RAN. 520 p. [in Russian].

Gromov I.M. \& Polykov I.Ya. 1977. [ Voles (Microtinae). Fauna of the USSR, Mammals]. Vol.111. No.8. Leningrad: Nauka. 504 p. [in Russian].

Guthrie R.D. 2003. Rapid body size decline in Alaskan Pleistocene horses before extinction// Nature. Vol.426. P.169-171.

Kamilari M., Tryfonopolus G., Fraquedakis-Tsolis S. \& Chondropolus B. 2013. Geometric morphometrics on Greek house mouse populations (Mus musculus domesticus) with Robertsonian and all-acrocentric chromosomal arrangements // Mammalian Biology. Vol.78. P.241-250.

Kaya A., Gharakhloo M.M. \& Coşkun Y. 2018. Geographic variation in the skull morphology of Ellobius lutescens
Thomas, 1897 (Mammalia: Rodentia) by geometric morphometric analyses // Vertebrate Zoology. Vol.68. No.2. P.157-164.

Kerey I.E., Meriç E., Tunoğlu C., Kelling G., Brenner R.L. \& Doğan A. U. 2004. Black Sea-Marmara Sea Quaternary connections: new data from the Bosphorus, İstanbul, Turkey// Palaeogeography, Palaeoclimatology, Palaeoecology. Vol.204. No.3-4. P.277-295.

Khrustaleva I.V., Mikhailov N.V., Schneiberg I.I., Zherebtsov N.A., Slesarenko N.A. \& Krishtoforova B.V. 1994. [Anatomy of Domestic Animals]. Moscow: Kolos. 703 p. [in Russian].

Klingenberg C.P. 2011. MorphoJ: an integrated software package for geometric morphometrics // Molecular Ecology Resources. Vol.11. P.353-357.

Kryštufek B. \& Vohrálik V. 2005. Mammals of Turkey and Cyprus. Rodentia I: Sciuridae, Dipodidae, Gliridae, Arvicolinae. Ljubljana: Univerza na Primorskem, Znanstveno-raziskovalno središče Koper, Založba Annales, Zgodovinsko društvo za južno Primorsko. 292 p.

Kryštufek B., Vohrálik V., Zareie R. \& Özkan B. 2009. Mitochondrial cytochrome $b$ sequences into the speciation of social voles in southwest Asia // Biological Journal of Linnaean Society. Vol.98. No.1. P.121-128.

Kryštufek B., Zorenko T., Bontzorlos V., Mahmoudi A., Atanasov N. \& Ivajnšič D. 2018. Incipient road to extinction of a keystone herbivore in south-eastern Europe: Harting's vole (Microtus hartingi) under climate change // Climatic Change. Vol.149. No.3-4. P.443-456.

Marder O., Malinsky-Buller A., Shahack-Gross R., Ackermann O., Ayalon A., Bar-Matthews M., Goldsmith Y., Inbar M., Rabinovich R. \& Hovers E. 2011. Archaeological horizons and fluvial processes at the Lower Palaeolithic open-air site at Revadim (Israel) // Journal of Human Evolution. Vol.60. No.4. P.508-522.

Markov G., Yiğit N., Çolak E., Kocheva1 M. \& Gospodinova M. 2014. Epigenetic diversity and similarity of the voles of "guentheri" group (Mammalia: Rodentia) in Anatolian Peninsula and southeastern part of the Balkan Peninsula // Acta Zoologica Bulgarica. Vol.66. P.159-164.

McHugh C.M.G., Gurung D., Giosan L., Ryan W.B.F., Mart Y., Sancar U., Buckles L. \& Çagatay M.N. 2008. The last reconnection of the Marmara Sea (Turkey) to the World Ocean: A paleoceanographic and paleoclimatic perspective // Marine Geology. Vol.255. No.1-2. P.64-82.

Millien V. 2006. Morphological evolution is accelerated among island mammals // PLoS Biology. Vol.4. No.10. e-321. P.1863-1868.

Millien V. 2011. Mammals evolve faster on smaller islands // Evolution. Vol.6. P.1935-1944.

Musser G.G. \& Carleton M.D. 2005. Superfamily Muroidea // Wilson D.E. \& Reeder D.M. (eds.). Mammal Species of the World. Baltimore: Johns Hopkins University Press. Vol.2. P.894-1531.

Orbach D.N., Hedrick B., Würsig B., Mesnick S.L \& Brennan P.L.R. 2017. The evolution of genital shape variation in female cetaceans // Evolution. Vol.72. P.261-273.

Pavlinov L.Ya. \& Mikeshina N.G. 2002. [Principles and methods of geometric morphometrics] // Zhurnal Obshchei Biologii. Vol.63. No.6. P.473-493 [in Russian].

RohlfF.J. 2016. Morphometrics at Suny Stony Brook. Available at https://life.bio.sunysb.edu/morph/index.html. 
Schmidt N.M. \& Jensen P.M. 2003. Changes in mammalian body length over 175 years - Adaptations to a fragmented landscape? // Conservation Ecology. Vol.72. P.1-7.

Thanou E., Tryfonopoulos G., Chondropoulos B. \& Fraguedakis-Tsolis Et.S. 2012. Comparative phylogeography of the live Greek vole species infers the existence of multiple South Balkan subrefugia // Italian Journal of Zoology. Vol.79. No.3. P.363-376.

Voino M.S. 1994. [Brain]// Sokolov V.E. \& Bashenina N.V. (eds.) [Common Vole: Sibling-species Microtus arvalis and $M$. rossiameridionalis]. Moscow: Nauka. P.52-71 [in Russian].

Voyta L.L., Omelko V.E. \& Petrova E.A. 2013. [Analysis of the morphometrics variability and intraspecific structure of Sorex minutisimus Zimmerman, 1780 (Lipotyphla: Soricidae) in Russia] // Proceedings of the Zoological Institute RAS. Vol.317. No.3. P.332-351 [in Russian, with English summary].

Wilczyński J., Tomek T., Nadachowski A., Miękina B., Rzebik-Kowalska B., Pereswiet-Soltan A., Stworzewicz E., Szyndlar Z., Marciszak A. \& Lõugas L. 2016. Faunal record and environmental changes during Holocene and Pleistocene // Kaczanowska M., Kozłowski J. \& Sampson A. (eds.). The Sarkenos Cave at Akraephnion, Boeotia, Greece. Vol.2. The Early Neolithic, the Mesolithic and the final Palaeolithic. Krákow: Polish Academy of Arts and Sciences. P.63-150.

Yaltırak C., Sakinç M. \& Oktay F.Y. 2000. Westward propagation of North Anatolian fault into the northern Aegean: timing and kinematics. Comment and reply // Geology. Vol.28. P.187-188.

Yaskin V.A. \& Lenec L.I. 1996. Specific features of the brain structure of the common vole sibling species // Zoolo- gicheskii Zhurnal. Vol.75. No.11. P.1715-1720 [in Russian, with English summary].

Yiğit N. \& Çolak E. 2002. On the distribution and taxonomic status of Microtus guentheri Danford and Alston, 1880 and Microtus lydius Blackler, 1916 (Mammalia: Rodentia) in Turkey // Turkish Journal of Zoology. Vol.26. P.197-204.

Yiğit N., Çetintürk D. \& Çolak E. 2017. Phylogenetic assessment of voles of the Guentheri Group (Mammalia: Microtus) in Turkish Thrace and Western Anatolia // European Zoological Journal. Vol.84. No.1. P.252-260.

Yiğit N., Markov G., Çolak E., Kocheva M., Saygılı F., Yüce D. \& Çam P. 2012. Phenotypic features of the 'guentheri' group vole (Mammalia: Rodentia) in Turkey and southeast Bulgaria: evidence for its taxonomic detachment // Acta Zoologica Bulgarica. Vol.64. No.1. P.23-32.

Zima J., Arslan A., Benda P., Macholàn M. \& Kryštufek B. 2013. Chromosomal variation in social voles: a Robertsonian fusion in Günter's vole // Acta Theriologica. Vol.58. P.255-265.

Zorenko T. \& Golenishchev G. 2015. The spermatozoa structure peculiarities of the subgenus Sumeriomys (Rodentia, Arvicolinae, Microtus) // Russian Journal of Theriology. Vol.14. No.1. P.105-111.

Zorenko T.A. 2013. [Social Voles of the Subgenus Sumeriomys: Systematics, Biology and Behavior]. Saarbrücken: Palmariun Academic Publishing. 541 p. [in Russian].

Zorenko Z., Atanasov N. \& Golenishchev F. 2016. Behavior and partial reproductive isolation between the European and Asian forms of Harting' vole Microtus hartingi (Rodentia, Arvicolinae) // Russian Journal of Theriology. Vol.15. No.2. P.133-150. 